\title{
Conrad Gesner: physician, naturalist and linguist
}

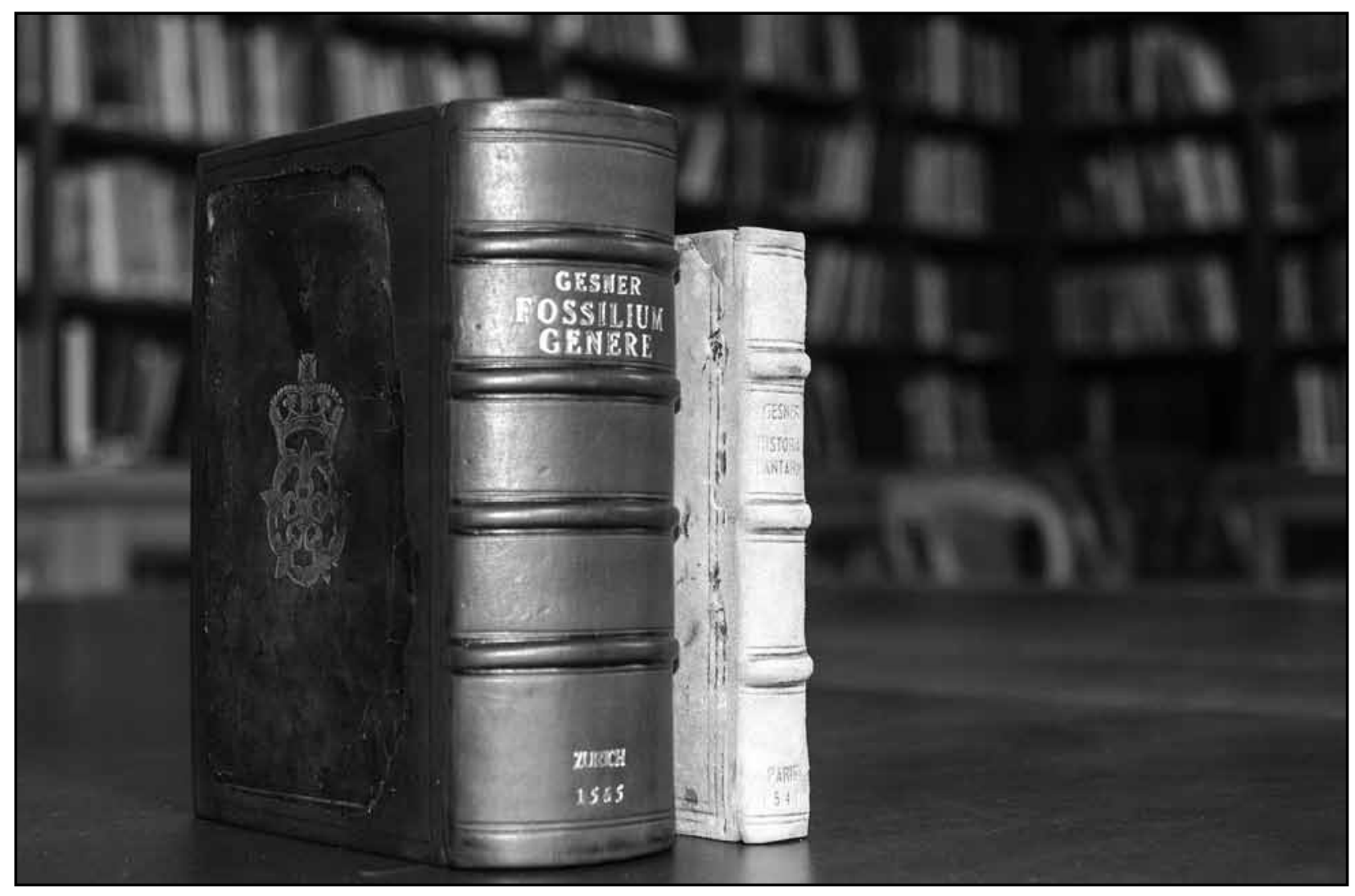

FIGURE I Conrad Gesner books in the College Library

The College Library contains an impressive and valuable collection of books written by Conrad Gesner. Gesner (1516-1565) was Swiss and is best known for his systematic compilations of information on animals and plants.

Conrad was the son of a poor furrier. His schooling was funded by a great-uncle who grew and collected medicinal herbs which inspired Gesner's life-long interest in natural history. Gesner studied at Basle, Paris and Montpellier before becoming professor of Greek at Lausanne, and finally professor of medicine and town physician at Zürich.

His numerous writings covered a vast range of topics and those on botany, zoology, medicine and pharmacology became standard reference works throughout Europe for over 200 years. He also made important contributions to classical philology, theology and the study of linguistics. In 1545, Gesner published a medical paper on the benefits of milk and in the same year he compiled the first known bibliography. The book listed about 1800 authors (in alphabetical order) with the titles of their works and evaluations of each work.

In |55| Gesner described brown adipose tissue as 'neither fat, nor flesh - but something in between'. He was the first to describe this although it took scientists another 450 years to prove it. Gesner regarded mountains as one of the great wonders of nature and he describes climbing Mount Pilate (near Lake Lucerne) in 1555. He tried to climb a mountain every year, primarily to collect alpine plants but also for the good of his health. He died in Zürich during the 1565 bubonic plague epidemic.

\section{Opera botanica per duo saecula desiderata vitam} auctoris et operis historiam

Gesner is remembered by the family Gesneriaceae (the African violet genus) named in honour of him by Linnaeus. Gesner was the first to describe the tulip in Europe. Linnaeus named it Tulipa Gesneria.A small genus of moths is also named after Gesner.

Historia plantarum et vires ex Dioscoride, Paulo Aegineta, Theophrasto, Plinio et recentioribus Graecis...

Gesner's first botanical work contains an alphabetical list of plants taken from the works of Dioscorides, Paul of Aegina, Theophrastus and Pliny. His notes and about I500 illustrations were passed on to his friend Caspar 


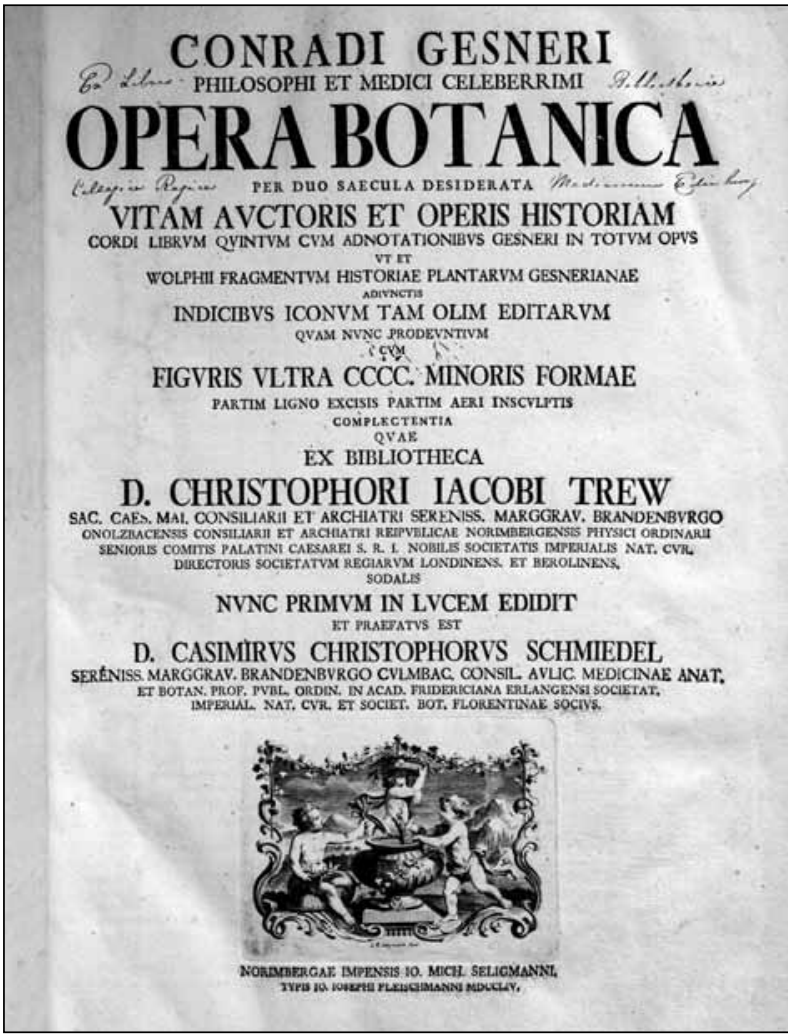

FIGURE 2 Gesner K, Trew C J, Schmidel CC, Cordus V. Opera botanica per duo saecula desiderata vitam auctoris et operis historiam. Norimbergae: Impensis lo. Mich. Seligmanni. Typis. losephi Fleischmanni; 1754

Historia plantarum et vires ex Dioscoride, Paulo Aegineta, Theophrasto, Plinio et recentioribus Graecis...

Gesner's first botanical work contains an alphabetical list of plants taken from the works of Dioscorides, Paul of Aegina, Theophrastus and Pliny. His notes and about 1500 illustrations were passed on to his friend Caspar Wolf. However, Wolf was a physician, not a botanist, so Historia plantarum and Opera botanica were not published until the mid-18th century.

De omni rerum fossilium genere, gemmis, lapidibus, metallis, et huius modi, libri aliquot

This collection contains eight separate treatises on the subjects of fossils, gems and metals, all edited by Gesner and with his general introduction and extensive commentaries. It is the first printed work to contain illustrations of fossils and crystals.

Although not the creator of the pencil, Gesner is the first to use an image of one in the De Rerum Fossilium. Anecdotal evidence supports the idea that Shakespeare and the disciples of Michelangelo also used the humble pencil.

Jane Hutcheon

Sibbald Library Rare Books Volunteer. Formerly Head of Library Services, Royal Botanic Garden Edinburgh

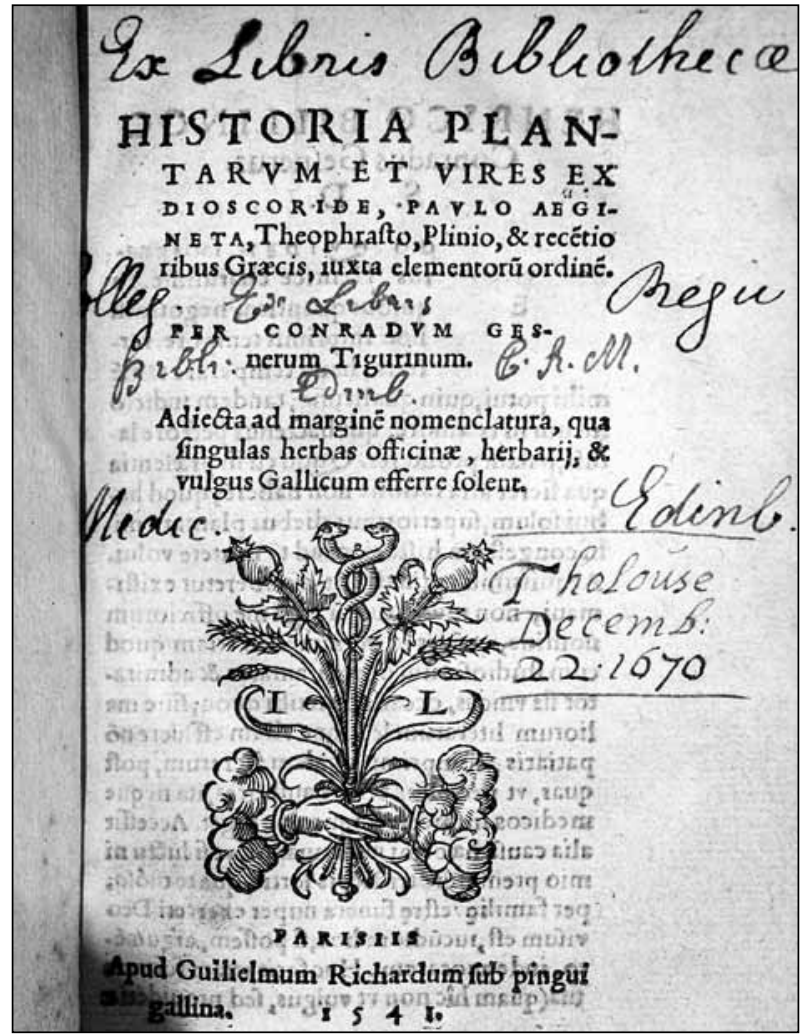

FIGURE 3 Gesner K. Historia plantarum et vires ex Dioscoride, Paulo Aegineta, Theophrasto, Plinio et recentioribus Graecis. Parisiis: apud Guilielmum Richardum; I54I

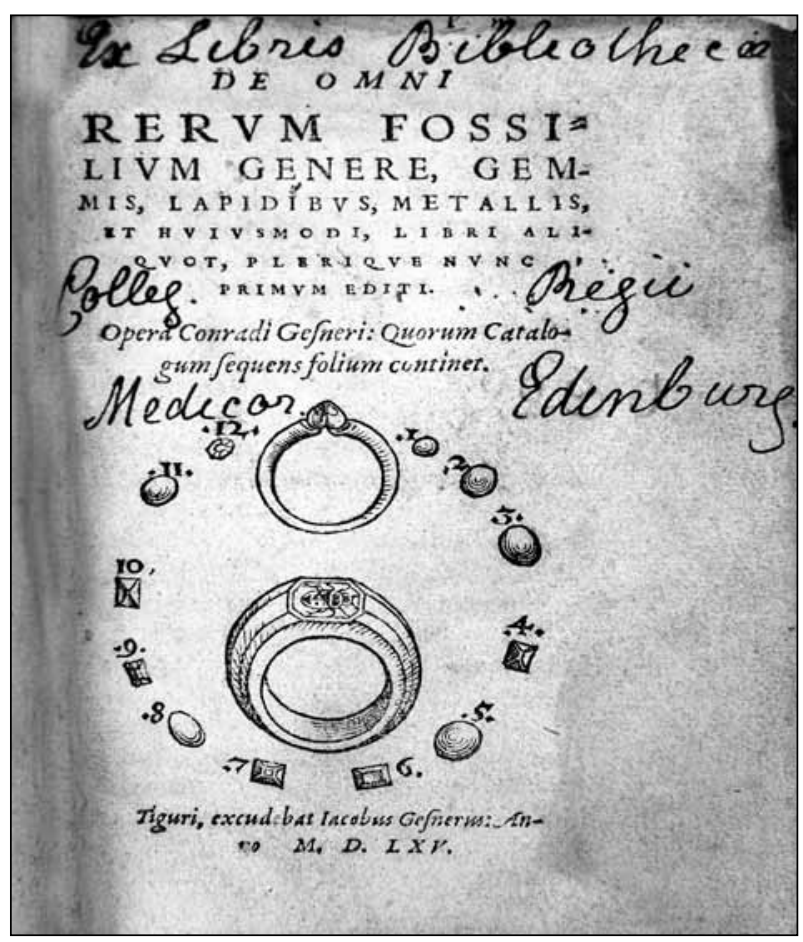

FIGURE 4 Gesner K. De omni rerum fossilium genere, gemmis, lapidibus, metallis, et huius modi, libri aliquot. 8 parts Tiguri: excudebat Jacobus Gesnerus; I565 